ESPAÇO IMAGEM

IMAGing SPACE

Responsável: Manoel Barros Bértolo

\title{
Síndrome de Fong ou Síndrome Unha-Patela
}

\section{Fong Syndrome or Nail-Patella Syndrome}

Figura 1 - Unhas displásicas; perda de pregueamento cutâneo sobre a interfa-langiana distal.

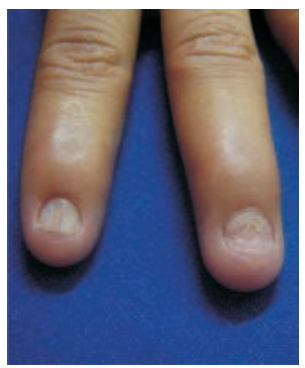

Figura 2 - Deformidades redutíveis em pescoço de cisne.

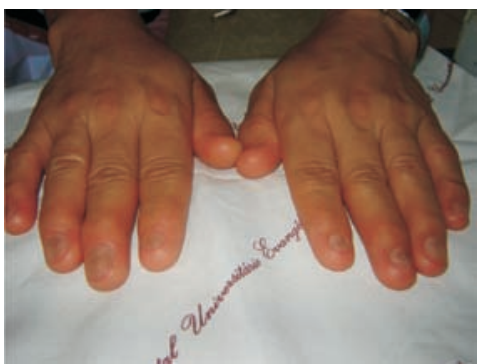

Figura 3 - Radiografia simples de bacia mostrando cornos ilíacos.

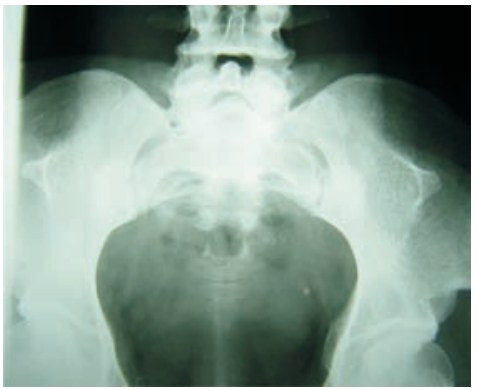

Figura 4 - Radiografia de joelho mostrando patela rudimentar.

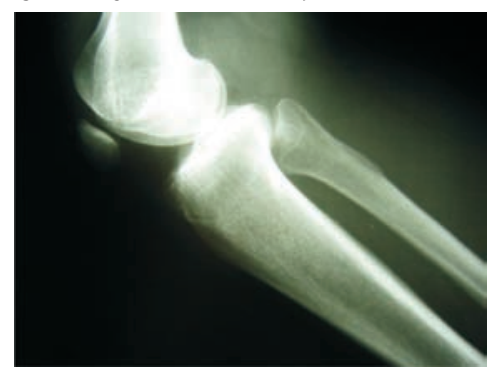

Paciente de 26 anos, sexo feminino, vem à consulta por dor em membros inferiores com características mecânicas, mais acentuadas em joelhos, de pelo menos dez anos de duração. Ao exame físico, observou-se baixa estatura $(1,47 \mathrm{~cm})$. Nas mãos havia deformidades redutíveis em pescoço de cisne (de $2^{\circ}, 3^{\circ}$ e $4^{\circ}$ dedos de ambas as mãos), unhas distróficas com perda do pregueamento cutâneo sobre as interfalangianas distais. (Figuras 1 e 2); pé plano bilateral. A paciente desconhecia seus pais biológicos. Um filho tinha as mesmas alterações ungueais. $\mathrm{O}$ exame radiológico mostrou cornos ilíacos bilaterais (Figura 3) e patelas rudimentares (Figura 4). O parcial de urina era normal, creatinina de 0,6 mg/dL; exame oftalmológico foi normal.

A síndrome unha-patela ou síndrome de Fong é uma síndrome rara que afeta 1:50.000 indivíduos. É causada por perda da função do gene LMXIB situado no cromossoma 9. Sua expressão é variável, mas a tétrade considerada clássica é a de hipoplasia ungueal dos joelhos e do cotovelo e a presença de cornos ilíacos. Este último achado de imagem é considerado patognomônico para a doença. Outros achados são os de lordose, cifose, pterígio de cotovelo, ausência de fíbula, displasia da primeira costela e de malformações claviculares e de crânio. Alterações de ligamentos, tendões e músculos com hipotrofia e fraqueza têm sido descritos. O aparecimento de deformidade em pescoço de cisne redutível como a vista nesta paciente é descrito em $58 \%$ dos casos.

Glaucoma (causado pela presença de câmara anterior ocular rasa) e disfunção renal (por má-formação de colágeno tipo 4 da membrana basal) são achados sistêmicos que podem estar presentes. Estudos de histologia renal em casos de insuficiência renal, o que acontece em $1 / 3$ dos pacientes, mostram glomerulosclerose focal.

Caso encaminhado por Leonardo M. Schmidt, Ana Paula Beckhauser, Liz Wallin, Marilia Barreto Silva e Thelma L. Skare, do Serviço de Reumatologia do Hospital Universitário Evangélico de Curitiba, e-mail: tskre@onda.com.br 